\title{
C4 null phenotypes among lupus erythematosus patients are predominantly the result of deletions covering C4 and closely linked 21-hydroxylase
} A genes

\author{
JUKKA PARTANEN*, SAIJA KOSKIMIES*, AND EIJA JOHANSSON \\ From *the Finnish Red Cross Blood Transfusion Service, Tissue Typing Laboratory, Helsinki; and the \\ Department of Dermatology, University Central Hospital, Helsinki, Finland.
}

SUMmaRY Two genes, $\mathrm{C} 4 \mathrm{~A}$ and $\mathrm{C} 4 \mathrm{~B}$, encoding the fourth component of the complement system are linked to the HLA complex. C4 defects or C4 'null' genes can predispose to an autoimmune disease, lupus erythematosus (LE). We have used Southern blotting techniques to analyse genomic DNA from 23 patients with LE and from healthy controls, to evaluate the molecular basis of the $\mathrm{C} 4$ null phenotypes. In addition to the high frequencies of $\mathrm{C} 4$ null phenotypes and HLA-B8, DR3 antigens, confirming earlier results, we observed that among the patients both the $\mathrm{C} 4 \mathrm{~A}$ and $\mathrm{C} 4 \mathrm{~B}$ null phenotypes mostly resulted from gene deletions. Among the controls only the $\mathrm{C} 4 \mathrm{~A}$ null phenotypes were predominantly the result of gene deletions. In all cases these $\mathrm{C} 4$ gene deletions also extended to a closely linked pseudogene, 21-hydroxylase $\mathrm{A}$ (21-OHA). Altogether, $52 \%$ of the patients and $26 \%$ of the controls carried a C4/21-OHA deletion.

Genetic studies ${ }^{12}$ of patients with lupus erythematosus (LE), an autoimmune disease, have shown that certain histocompatibility complex (MHC) markers predispose to LE, especially HLA-DR3 and a haplotype HLA-B8, DR3, as well as defects in the early components of the classical complement pathway, $\mathrm{C} 1, \mathrm{C} 2$, and $\mathrm{C} 4 .^{3}$

We have approached the role of the $\mathrm{C} 4$ defects, or C4 'null' alleles, in LE by determining HLA and C4 allotypes and the molecular basis of $\mathrm{C} 4$ null phenotypes in two subgroups of LE, namely in subacute cutaneous LE (SCLE) and in systemic LE (SLE). The study groups represent the two extremes of the clinical spectrum of LE. The characteristics of $\mathrm{SCLE}^{2}$ are skin manifestations, photosensitivity, and a good prognosis, whereas patients with $S^{1} E^{12}$ have more severe renal or central nervous system involvement or both with a poor prognosis. After cloning the $\mathrm{C} 4$ genes $^{45}$ a more detailed analysis of the $\mathrm{C} 4$ genes and defects was possible. The $\mathrm{C} 4$ gene region is located in the MHC between the HLA-B and HLA class II genes. It includes the duplicated $\mathrm{C} 4$ genes (C4A and $\mathrm{C} 4 \mathrm{~B}$ ) and steroid 21-hydroxylase

Received for publication 18 July 1987

Revised version accepted for publication 13 November 1987.
(21-OHA and 21-OHB) genes. ${ }^{5}$ There is evidence ${ }^{5-8}$ that the number of $\mathrm{C} 4$ genes per chromosome may vary; certain $\mathrm{C} 4$ null phenotypes result from a gene deletion, whereas some chromosomes express three C4 products. Particularly, the C4A null phenotype in HLA-B8, DR3 haplotype is the result of a large deletion covering the $\mathrm{C} 4 \mathrm{~A}$ and 21-OHA genes. The presence of this deletion in the haplotype associated with LE and many other autoimmune diseases prompted us to study the $\mathrm{C} 4$ gene region in LE in more detail using the Southern blotting technique.

\section{Subjects and methods}

PATIENTS

The first group included 11 patients ( 10 women, one man) with subacute cutaneous LE. ${ }^{9}$ Duration of the disease varied from three to 37 years (mean 14.9 years). All the patients had pronounced photosensitivity and skin changes as the main manifestation. The clinical picture corresponded to that described before $^{9}$ and the patients fulfilled no more than four of the ARA criteria for SLE. The second group included 12 patients (11 women, one man) with severe systemic LE. Duration of the disease varied from two to 21 years (mean 9.7 years). All the 
patients fulfilled more than five of the ARA criteria for SLE.

\section{CONTROLS}

DNA was prepared from 23 healthy blood donors from the Finnish Red Cross Blood Transfusion Service, Helsinki, Finland. The HLA and complement $\mathrm{Bf}$ and $\mathrm{C} 4$ frequencies did not differ from a reference Finnish population. ${ }^{10} 11$ The reference HLA-DR frequencies were based on typing of 322 blood donors.

HLA, BF AND C4 T⿱YPINGS

HLA, ${ }^{10} \mathrm{Bf},{ }^{12}$ and $\mathrm{C}^{13}$ typing was performed using standard methods. The $\mathrm{C} 4$ null alleles were assigned according to the relative staining intensities of the $\mathrm{C} 4 \mathrm{~A}$ and $\mathrm{C} 4 \mathrm{~B}$ protein bands measured by a scanning apparatus (Helena Laboratories Ltd) as described previously. ${ }^{14}$ This method could not identify the presence of $\mathrm{C} 4$ null heterozygosity in both $\mathrm{C} 4$ loci, that is, $\mathrm{C} 4 \mathrm{~A} 3, \mathrm{O} \mathrm{B} 1, \mathrm{O}$ could not be distinguished from $\mathrm{C} 4 \mathrm{~A} 3$, $3 \mathrm{~B} 1,1$, thus a $\mathrm{C} 4$ null phenotype was assigned only when the intensity of the $C 4 A$ (or C4B) band was less than half of C4B (or C4A). A $\mathrm{C} 4$ null was also assigned if a deletion of a $\mathrm{C} 4$ gene could be observed with Southern blotting. The nomenclature for the $\mathrm{C} 4$ alleles was according to Mauff $e t a l,{ }^{15}$ and 'complotypes' were abbreviated, for example, S31 means $\mathrm{Bf}^{*} \mathrm{~S}, \mathrm{C} 4 \mathrm{~A}^{*} 3, \mathrm{C}^{*} \mathrm{~B}^{*} 1$.

\section{SOUTHERN BLOTTING}

Genomic DNA was digested with restriction enzymes HindIII, KpnI, TaqI, and $X b a I$ (Promega, Madison, WI). The digested DNA samples were size separated by $0 \cdot 8 \%$ agarose gel electrophoresis, denatured, and blotted on Hybond-N nylon filters. ${ }^{8}$ Prehybridisation and hybridisation (48 hours at $42^{\circ} \mathrm{C}$ ) were in $50 \%$ formamide, $6 \times \mathrm{SSC}$, $5 \times$ Denhardt's, $0.1 \%$ SDS, $50 \mathrm{mmol} / 1$ phosphate buffer, and $0 \cdot 1 \mathrm{mg} / \mathrm{ml}$ denatured herring DNA. Filters were washed first in $2 \times \mathrm{SSC}$ at room temperature and then twice in $0.3 \times \mathrm{SSC}$ at $42^{\circ} \mathrm{C}$. Restriction enzyme fragments were visualised by autoradiography. A full length $\mathrm{C} 4$ specific cDNA probe p AT-A, ${ }^{4}$ and a $21-\mathrm{OH}$ specific probe p21-K $4,{ }^{16}$ were used. The pAT-A probe was labelled by nick translation (Amersham) and a $0.9 \mathrm{~kb} B g l$ fragment of p21-K4 was labelled by multiprime DNA labelling (Amersham). The probes were kindly provided by Dr Michael C Carroll, Harvard University, Boston.

INTERPRETATION OF SOUTHERN BLOTS Enzymes TaqI and $K p n I$ produce restriction enzyme fragments which have been shown 61617 to be, with certain exceptions, ${ }^{6}{ }^{18}$ diagnostic for C4A (7.0 kb TaqI, 12.0 kb KpnI), C4B $(6 \cdot 4,6 \cdot 0,5 \cdot 4$ kb Taq I $3.5 \mathrm{~kb} K p n \mathrm{I}), 21-\mathrm{OHA}(3.2 \mathrm{~kb}$ TaqI, $4.0 \mathrm{~kb}$ KpnI) and 21-OHB (3.7 kb TaqI, 3.0 KpnI). A deletion covering the $\mathrm{C} 4 \mathrm{~A}$ and $21-\mathrm{OHA}$ genes ${ }^{5-8}$ generate․ㅡㄴ. specific fragments, for example, in TaqI $(6.4 \mathrm{~kb}$ and HindIII $(8.0 \mathrm{~kb})$ digests, and the deletion wa\& assigned if these fragments were observed with the $\mathrm{C} 4$ probe. For the other $\mathrm{C}^{5}{ }^{6}$ and $21-\mathrm{OH}$ deletions $\overrightarrow{0}$ there are no known specific markers, so they were determined by comparing the intensities of the gene् specific bands in TaqI and KpnI analysis. The TaqR and KpnI fragments represent the $5^{\prime}$ ends of the $\mathrm{C}_{\mathrm{B}}$ genes. The intensities were measured by an autoi matic scanner (Scanner Oy Ltd, Helsinki). Only the bands in a single lane, and in a single hybridisation were compared, The results were expressed as numerical ratio of the A specific band intensities too the $B$ intensities. It should be noted that the term 'deletion' here indicates only the apparent lack of these fragments.

\section{Results}

HLA, BF, AND C4 PHENOTYPES

Table 1 shows the frequencies of HLA-B8, DR2 and $\mathrm{C} 4$ null alleles in the two patient groups (SCLE and SLE), in the controls, and in the Finnists reference population. The comparison showed tha $\mathbb{D}$ in both patient groups the frequencies of HLA-B\& and DR 3 were about twice those in the controls ans the reference population. Furthermore, the fre quency of C4AO $(60 \%$ in SCLE and $54 \%$ in SLE group), but not $\mathrm{C} 4 \mathrm{BO}$, was clearly higher among the patients than among the controls $(22 \%, \mathrm{p}<0.05)$ The increased frequency of HLA-DR2 $(64 \% v 33 \%$ in SLE, NS, and $25 \%$ in the controls, $\mathrm{p}<0.05 \%$.

TABLE 1 Frequencies of the patients with the HLA markers and $C 4 / 21-O H A$ gene deletions (C4 del) associated with $L E-$ in three study groups and in the reference population.

\begin{tabular}{|c|c|c|c|c|}
\hline & SCLE & $S L E$ & Control & Reference \\
\hline HLA-B8 & $36 \%(4 / 11)$ & $50 \%(6 / 12)$ & $18 \%(4 / 23)$ & $19 \% *$ \\
\hline HLA-DR2 & $64 \%(7 / 11)$ & $33 \%(3 / 9)$ & $25 \%(5 / 20)$ & $33 \%$ \\
\hline HLA-DR3 & $45 \%(5 / 11)$ & $44 \%(4 / 9)$ & $20 \%(4 / 20)$ & $32 \%$ \\
\hline $\mathrm{C} 4 \mathrm{AO}$ & $6(1) \%(6 / 10)$ & $54 \%(6 / 11)$ & $22 \%(5 / 23)$ & $18 \% *$ \\
\hline C4Adel & $36 \%(4 / 11)$ & $50 \%(6 / 12)$ & $22 \%(5 / 23)$ & $-\$$ \\
\hline C4BO & $40 \%(4 / 10)$ & $45 \%(5 / 11)$ & $43 \%(10 / 23)$ & $29 \% \$$ \\
\hline C4Bdel & $27 \%(3 / 11)$ & $17 \%(2 / 12)$ & $9 \%(2 / 23)$ & $-\$$ \\
\hline $\begin{array}{l}\text { C4AO or } \\
\text { C4BO } \\
\text { C4Adel or }\end{array}$ & $90 \%(9 / 10)$ & $82 \%(9 / 11)$ & $61 \%(14 / 23)$ & $47 \%+$ \\
\hline C4Bdel & $54 \%(6 / 11)$ & $50 \%(6 / 12)$ & $26 \%(6 / 23)$ & 一 \\
\hline \multicolumn{5}{|c|}{$\begin{array}{l}{ }^{*} \mathrm{p}=<0 \cdot 05, \mathrm{SCLE}+\mathrm{SLE} v \text { controls. } \\
+\mathrm{p}=<0 \cdot 05 \text {. SCLE } v \text { controls, } \mathrm{p}=0 \cdot 18 \text { SCLE } v \text { SLE. } \\
+=<0 \cdot 10 . \text { SCLE }+ \text { SLE } v \text { controls. } \\
\$ \mathrm{p}=>0 \cdot 10 . \mathrm{NS} .\end{array}$} \\
\hline
\end{tabular}


seemed to be an addtional marker and the only specific marker for the SCLE group.

C4 AND 2 I-HYDROXYLASE ( 2 I-OH) GENES Based on TaqI, KpnI, and HindIII analysis (see Subjects and methods), 10 of the 23 patients (cases 1 to 4 with SCLE and 12 to 17 with SLE) had the normal restriction fragment patterns suggesting an absence of deletions. An example of the normal TaqI and KpnI patterns obtained with the C4 and 21-OH probes is shown in the figure, sample C2. Five of these 10 patients were phenotyped as having a heterozygous $\mathrm{C} 4$ null allele.

Twelve of the 23 patients (6 to 11 and 18 to 23 in table 2) had at least one deletion in the gene region. Seven patients $(6,7,8$, and 18 to 21$)$ showed the $6.4 \mathrm{~kb}$ TaqI (two examples are shown in the figure) and the $8.0 \mathrm{~kb}$ HindIII bands which have been reported to be specific markers for a deletion of the $\mathrm{C} 4 \mathrm{~A}$ and 21-OHA genes and to be found in HLA-B8, BfS, C4AO, B1, DR3 haplotype. The deletion was further supported by the reduced intensities of the 21-OHA gene specific bands in TaqI and HindIII patterns. An example of TaqI and KpnI band patterns of a homozygote ${ }^{8}$ for haplotype $\mathrm{B}$ is shown in the figure, sample $\mathrm{C} 1$.

Three patients $(11,22,23)$ had both the $\mathrm{C} 4 \mathrm{~A} / 21$ OHA deletion described above and a combined deletion of the $\mathrm{C} 4 \mathrm{~B}$ and 21-OHA genes in the other chromosome. In the TaqI analysis with the C4 probe, these patients had, firstly, the $6.4 \mathrm{~kb}$ band showing that in this chromosome they had only

TABIE $2 H L A-B, D R, B f$, and $C 4$ phenotypes, relative intensities of the 2I-OHA $121-\mathrm{OHB}$ and $\mathrm{C} 4 \mathrm{~A} \vee \mathrm{C} 4 \mathrm{~B}$ specific bands, and suggested gene deletions in patients with $S C L E(1-11)$ and SLE (12-23).

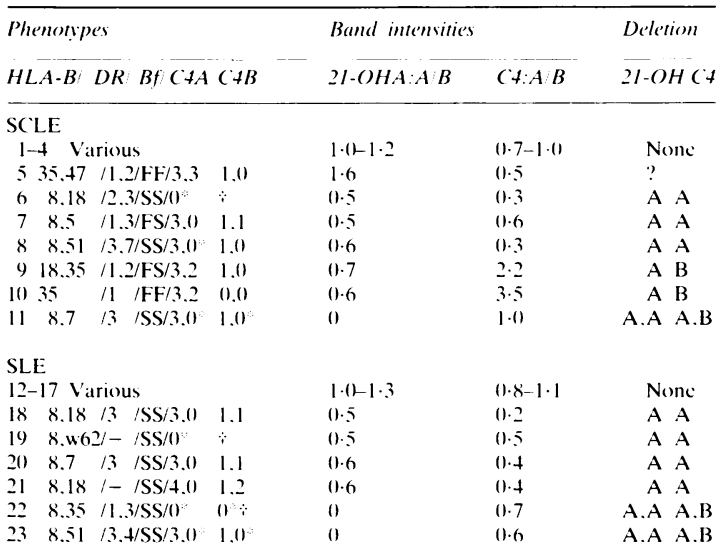

A C4 null allele determined only on the hasis of DNA analysis. $\therefore(t$ phenotspe could not be determined from the serum.

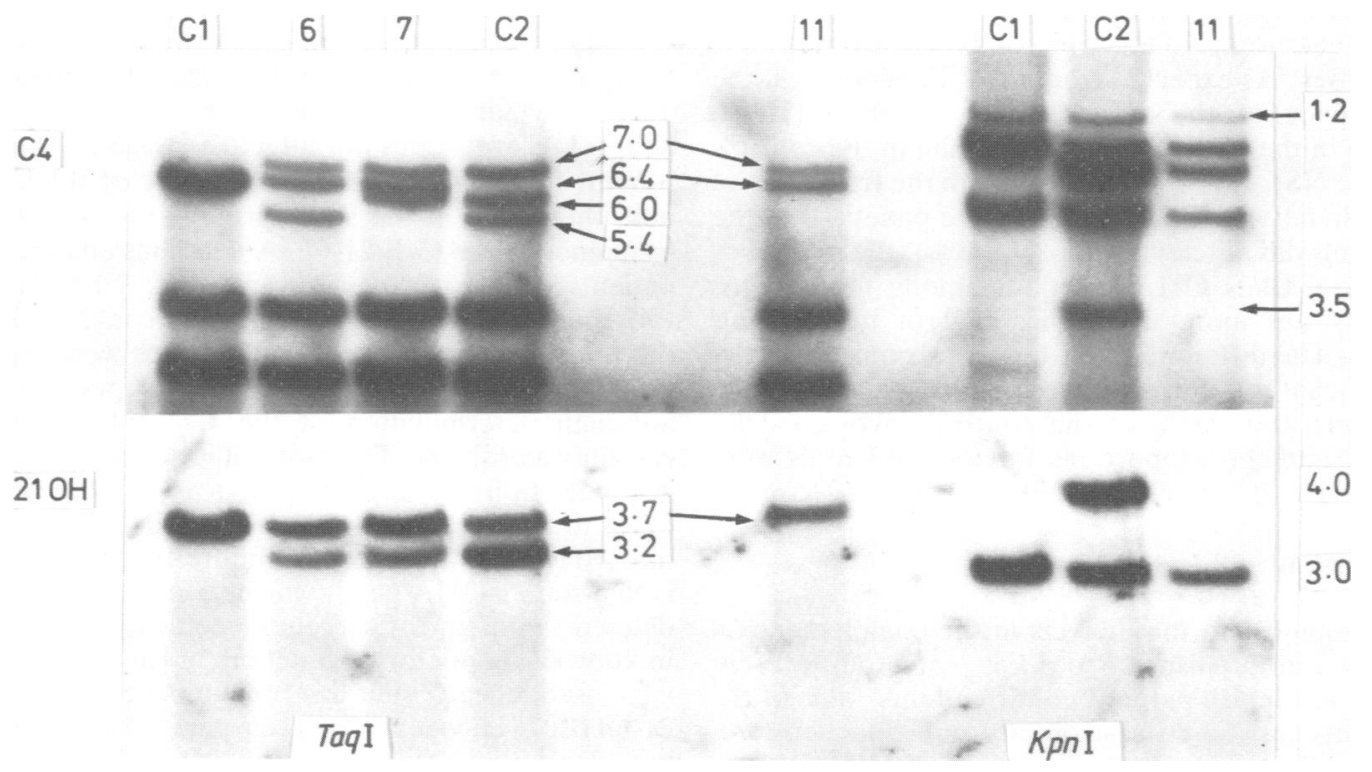

FIGURE Genomic DNA of patients 6, 7, and 11 and of two controls digested with Taql (left) and KpnI (right) and hybridised with the $\mathrm{C} 4$ and $21-\mathrm{OH}$ probes. The sizes of the bands are shown in $\mathrm{kb}$. Samples: $\mathrm{Cl}=$ a control homozygous for $H L A, B 8, D R 3, B f S, C 4 A O($ deletion), $B 1 ; C 2=$ a control without a deletion in the gene region. 
one C4B gene and no C4A gene, and, secondly, the $7.0 \mathrm{~kb}$ band showing that in the other chromosome they had a C4A gene without a C4B gene, because no $6.0 \mathrm{~kb}$ nor $5.4 \mathrm{~kb}$ was observed (figure). Lack of a $3.5 \mathrm{~kb} K p n I$ band (figure) confirmed this. ${ }^{19}$ Moreover, the $21-\mathrm{OH}$ probe did not detect the 21 OHA bands (figure) suggesting a homozygous deletion of the gene.

Patients 9 and 10 may have a heterozygous C4B/21-OHA deletion. Their C4B specific TaqI band $(6.0 \mathrm{~kb}$ in both cases) had an intensity of about half of the C4A specific $7 \cdot 0 \mathrm{~kb} T a q \mathrm{I}$ band, and, furthermore, the 21-OHA bands had a lower intensity than the 21-OHB bands (table 2). Their C4 phenotypes supported the result as both of them had C4BO. An accurate determination of the deletion would, however, require at least a family study, which was not possible.

The organisation of the $\mathrm{C} 4$ gene region in patient 5 could not be accurately determined. The intensity of the 21-OHA band was 1.6 times that of the 21OHB band (table 2) suggesting that there may be three 21-OHA and two 21-OHB genes. Using the C4 probe with TaqI, KpnI, and HindIII, the result did not differ from the normal population. However, enzyme $X b a I$ gave a band pattern suggesting a C4B gene duplication (data not shown) that was not observed in the other patients.

The frequencies of the patients and controls with the gene deletions are summarised in table 1 . The two patient groups, SCLE and SLE, did not differ from each other and were combined for statistical purposes. As expected from the $\mathrm{C} 4$ phenotypes, the frequency of the C4A/21-OHA deletion (10/23, $43 \%$ ) in the patients was higher than in the controls $(22 \%, N S)$. Interestingly, although the frequency of the phenotypic $\mathrm{C} 4 \mathrm{BO}$ between the patients and the controls did not deviate $(43 \% v 43 \%)$, the frequency of the $\mathrm{C} 4 \mathrm{~B} / 21-\mathrm{OHA}$ deletions among the patients $(22 \%)$ was more than twice that of the controls $(9 \%)$. The difference was, however, not statistically significant. Of the phenotypic $\mathrm{C} 4 \mathrm{~A}$ nulls, $83 \%$ of the patients and $100 \%$ of the controls involved deletions, and the proportions for the C4B nulls were $55 \%$ and $20 \%$, respectively.

\section{Discussion}

It is established that defects in the complement $\mathrm{C} 4$ genes can predispose to $\mathrm{LE},{ }^{13}$ and our present study in Finnish patients confirmed this: $\mathbf{9 0 \%}$ of the patients carried at least one $\mathrm{C} 4$ null. Furthermore, we confirmed the high frequency of HLA-B8 and DR3 in both subgroups of LE. The comparison between the two groups, SCLE and SLE, showed that they had similar MHC patterns except that HLA-DR2 might be a specific MHC marker for
SCLE.

HLA-B8, SO1, DR3 haplotype has beene shown ${ }^{6-8} 19$ to carry a large deletion of the C4A and 21-OHA genes. Therefore, we studied the nature of C4 null alleles in patients with LE in more detail using Southern blotting. With regard to $\mathrm{C} 4 \mathrm{~A}$, the increase in the frequency of the C4AO allele couldbe explained by the increased frequency of the genedeletions: the proportion of $\mathrm{C} 4 \mathrm{~A}$ deletions per $\mathrm{C} 4 \mathrm{~A} \vec{\omega}$ nulls did not differ between the patients and? controls. The proportion was high, about $80 \%$ of the C4A null phenotypes resulted from a deletion, and in all cases the deletion seemed to be of one simple type, that is, the same as described originally byw Carroll et al $^{19}$ in BfS, C4AO, B1 complotype. The molecular basis of the $\mathrm{C} 4 \mathrm{~B}$ null phenotypeso appeared to be more heterogeneous. Firstly, in contrast to the $\mathrm{C} 4 \mathrm{~A} / 21-\mathrm{OHA}$ deletion stronglyc associated with HLA-B8, DR3, the $\mathrm{C} 4 \mathrm{~B} / 21-\mathrm{OHA}$ deletions were observed with various HLA-B and DR antigens which may indicate independent origin ${ }_{\infty}^{\circ}$ of these deletions. Secondly, the deletions explained ${ }^{\circ}$ only half of the C4B null phenotypes. We could not? perform more detailed mapping of the C4B deletions, because none of the patients or the controls was homozygous. The interpretation of the C4 gene organisation on the basis of Southern blotting $\bar{\varnothing}$ clearly poses some problems, because it is not easy $\underset{\vec{F}}{\overrightarrow{2}}$ to distinguish between a gene deletion and a윽 duplication. This approach, when combined with phenotypic and family data, should, however, give a better picture of the role of $\mathrm{C} 4$ defects in diseases than $\mathrm{C} 4$ typing alone because, for example, variation in $\mathrm{C} 4$ levels does not affect the result.

With regard to the equal frequency of the $\mathrm{C} 4 \mathrm{~B} 3$. null phenotype in the study groups, the increased frequency of the $\mathrm{C} 4 \mathrm{~B} / 21-\mathrm{OHA}$ deletions among the $₹$ patients $(22 \% v 9 \%)$ was surprising. Undetectedo C4B null alleles among the patients could explain? this, but the fact that the study groups were typedo using the same criteria does not support this, although determination of the $\mathrm{C} 4$ null alleles is $\mathrm{N}$ certainly a problem. Therefore, it is possible that then gene deletions themselves play a role in suspecti-N bility to LE, together with other high risk factors $\sigma$ like MHC class II genes. An interesting hypothesis is that the 21-OHA gene, which seems always to be? deleted with the $\mathrm{C} 4$ genes, could have somes unknown regulatory function. The 21-OHA is a pseudogene $\mathrm{e}^{17}$ but its functional counterpart,

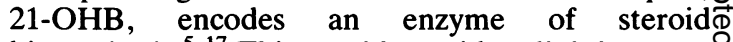
biosynthesis. ${ }^{517}$ This would provide a link between $\frac{?}{\mathbb{0}}$ HLA and the higher risk for autoimmunity among females. Moreover, a report ${ }^{7}$ has shown that the $21-2$ $\mathrm{OHA}$ gene, together with a $\mathrm{C} 4$ gene, was deleted ino 
two haplotypes associated with another autoimmune disease, type I diabetes. Thus, those $\mathrm{C} 4$ null alleles which result from a $\mathrm{C} 4$ and $21-\mathrm{OHA}$ deletion would cause a higher risk of autoimmunity than those without a deletion, because the $\mathrm{C} 4$ defect impairs the clearance of immune complexes, ${ }^{20}$ and the 21-OHA deletion changes the steroid balance. A possible effect of a 21-OHA deletion on the concentrations of corticosteroids and sex hormones would be worth testing. Another possibility is that only the $\mathrm{C} 4$ deletions would be the 'real' $\mathrm{C} 4$ null genes, that is, they are not expressed. The other C4 null phenotypes might result from, for instance, gene duplications actually expressing two identical C4 molecules as recently shown. ${ }^{18}$

The authors thank Ms Meeri Mannonen for technical assistance, and Dr Marianne Gripenberg, University Central Hospital, Helsinki, for providing samples from patients with SLE.

\section{References}

1 Walport MJ, Ficlder AHL, Batchelor JR. Genetics of systemic lupus crythenıatosus. In: Panayi GS, David CS, cds. Immunogenetics. London: Butterworth, 1984:157-76.

2 Gilliam JN. Immunopathology and pathogenesis of cutancous lupus crythematosus. In: Safai B. Good RA. cds. Immunodermatology. New York. London: Plenum Press, 1981:323-32.

3 Ross SC, Densen P. Complement deficiency states and infection: epidemiology, pathogenesis and consequences of neisserial and other infections in an immune deficiency. Medicine (Baltimore) 1984:63:243-73.

+ Belt KT. Carroll MC. Porter RR. The structural basis of the multiple forms of human complement component $\mathrm{C} 4$. Cell 1984:36:907-14.

5 Carroll MC, Belt KT, Palsdottir A, Yu Y. Molecular genetics of the fourth component of human complement and steroid 21hydroxylasc. Immunol Rev 1985;87:39-60.

- Schneider PM. Carroll MC. Alper CA. et al. Polymorphism of the human complement $\mathrm{C} 4$ and steroid 21-hydroxylase genes. Restriction fragment length polymorphisms revealing structural delctions, homoduplications, and size variants. J Clin Invest 1986;78:65()-7.
${ }^{7}$ Garlepp MJ, Wilton AN, Dawkins RL, White PC. Rearrangement of 21-hydroxylase genes in disease-associated MHC supratypes. Immunogenetics 1986;23:100-5.

* Partanen J, Peltonen L, Koskimies S, Carroll MC. DNA polymorphism of human HLA-linked complement $\mathrm{C} 4$ allotypes, including $\mathrm{C} 4$ null alleles, in the Finnish population. Hum Hered 1987:37:241-9.

${ }^{9}$ Sontheimer RD, Thomas JR, Gilliam JN. Subacute cutaneous lupus erythematosus. A cutaneous marker for a distinct lupus erythematosus subset. Arch Dermatol 1979;115:1409-15.

10 Lokki ML, Julin M. HLA-A, B, C gene and haplotype frequencies in the Finnish population. Tissue Antigens 1982;20:239-50.

1 Partanen J, Koskimies S. Human MHC class III genes, Bf and C4. Polymorphism, complotypes and association with MHC class I genes in the Finnish population. Hum Hered 1986:36:269-75.

12 Alper CA. Boenisch T, Watson L. Genetic polymorphism in human glycine-rich beta-clycoprotein. $J$ Exp Med 1972;135: 68-80.

1.3 Awdeh ZL. Alper CA. Inherited structural polymorphism of the fourth component of human polymorphism. Proc Natl Acad Sci USA 1980;77:3576-80.

it Partanen J, Koskimies S, Ilonen J, Knip M. HLA antigens and complotypes in insulin-dependent diabetes mellitus. Tissue Antigens 1986:27:291-7.

15 Mauff G, Alper CA, Awdeh ZL, et al. Statement on the nomenclature of human $\mathrm{C} 4$ allotypes. Immunobiology 1983;164:184-91.

${ }^{16}$ Carroll MC. Campbell RD, Porter RR. Mapping of steroid 21hydroxylase genes adjacent to complement $\mathrm{C} 4$ genes in HLA, the major histocompatibility complex in man. Proc Natl Acad Sci USA 1985;82:521-5.

17 Higashi Y, Yoshioka H, Yamane M, Gotoh O, Fujii-Kuriyama $\mathrm{Y}$. Complete nucleotide sequence of two steroid 21-hydroxylase genes tandemly arranged in human chromosome: a pseudogene and a genuine gene. Proc Natl Acad Sci USA 1986;83:2841-5.

is Yu CY. Campbell RD. Definitive RFLPs to distinguish between the human complement $\mathrm{C} 4 \mathrm{~A} / \mathrm{C} 4 \mathrm{~B}$ isotypes and major Rodgers/ Chido determinants: application to the study of $\mathrm{C} 4$ null alleles. Immunogenetics 1987:25:383-90.

14 Carroll MC. Palsdottir A, Belt KT. Porter RR. Deletion of complement $\mathrm{C} 4$ and steroid 21-hydroxylase genes in the HLA class III region. EMBO J 1985:4:2547-52.

${ }^{20}$ Schifferli JA, Ng YC, Peters DK. The role of complement and its receptor in elimination of immune complexes. $N$ Engl J Med 1986:315:488-95.

Correspondence and requests for reprints to Dr Jukka Partanen, FRC Blood Transfusion Service, Kivihaantie 7, SF-00310 Helsinki, Finland. 